\title{
BARRIERS BEFORE STUDENTS` ENTREPRENEURIAL INTENTIONS AND BUSINESS INITIATIVES - RESULTS BY EMPIRICAL STUDY OF BULGARIAN AND POLISH STUDENTS
}

\section{Introduction $^{1}$}

One of the main innate aspirations of people is to win, to succeed. Entrepreneurs are often seen as models for such success. A factor that undoubtedly helps young people to decide on an entrepreneurial path is an example. Success and "fail" stories of local and foreign entrepreneurs together with necessary knowledge ${ }^{2}$ create a solid basement of the business. Anyway, the implementation of entrepreneurial activity is associated with risktaking, which is an immanent characteristic regardless of business specific form. The risks that accompany entrepreneurship exist in each of the entrepreneurial process stages - they are significant in starting own business, but are not less in the next stages of development of entrepreneurial initiative. In contemporary context, entrepreneurial risk relates to the danger of material and financial losses, failures, lack of planned revenues in a changing economic environment. It is the result of uncertainty. The gradual accumulation of knowledge, including in the field of entrepreneurship, reveals to young people both new horizons for action and projects, and alerts about possible difficulties, dangers, losses and problem areas.

This article outlines the most important barriers for students that abandon or significantly reduce the execution of their entrepreneurial intentions and the start of new businesses. The barriers are based on data from a study conducted in early 2020 . The target group was students, who attend Entrepreneurship classes at universities. Two universities were selected i.e. the "St. Cyril and St. Methodius" University of Veliko Tarnovo, Bulgaria and the Maritime University of Szczecin, Poland.
The selection was strictly connected with the authors' place of employment. Three different groups on each university were selected: two from the bachelor level (1st semester and 4th semester) and one from the Master level. In mentioned semesters, the students have Entrepreneurship classes. The groups from the first semester were the most numerous i.e. 30 persons, while the groups from higher semesters have consisted of 15 people. All together 120 students were questioned. There were outlined the following research questions: how the nationality, year and field of study have connection with the barriers before students to start their own business initiative?

\section{Barriers before starting business initiatives} (by students) - some theoretical and practical aspects

In the studies and developments of theorists and practitioners much more often can be found data on what has led to the success ("success stories") of an entrepreneurial activity ${ }^{3}$. But it is an indisputable fact that every year at least a half of the newly formed companies close their activities. The probable reasons for this are diverse as some of them are related to the personality of the entrepreneur: they are both personal and related to his managerial skills. There are many publications with a list of most common reasons of failure in entrepreneurship $p^{4}$ :

- lack of a written business plan to support the development of the idea to a real business;

- lack of stable revenues from the activity;

- business opportunities are limited;

- inability to execute;

\footnotetext{
${ }^{1}$ The authors' participation in the article is as follows: Veneta Hristova - I, II.1, II.2, II.3 and II.5; Piotr Wołejsza Introduction, II.4 and conclusion.

${ }^{2}$ Pavlov, D., Sheresheva, M., Perello, M. (2017). The Intergenerational Small Family Enterprises as Strategic Entities for the Future of the European Civilization - A Point of View. Journal of Entrepreneurship \& Innovation, Issue 9, p. 124.

${ }^{3}$ Deneva, A. (2001). The small business - organization and problems. Economic world Library, 51, pp. 35-36. Svishtov, Tsenov Publishing house [in Bulgarian].

${ }^{4}$ See: 10 Reasons Why Entrepreneur Fail Their Business. HarvardEntrepreneurships. URL: https://www.harvard entrepreneurship.org/246/10-reasons-why-entrepreneur-fail-their-business.html (posted on July 2, 2020).
} 
ket;

- the presence of too many competitors in the mar-

- lack of intellectual property;

- inexperienced team;

- underestimation of part of the resources neces-

sary for the business;

- little or no marketing activity;

- early giving in.

A significant part of these failures form barriers to start own business. In a recent publication with a focus on barriers 5 main reasons are outlined": "no money barrier", "no time to start a business", "no health benefits nightmare", "no family support" and "no confidence in your abilities", i.e. the barriers have a source both outside the individual and directly related to her/him.

A much more detailed analysis is given in a crosscultural study from 2010 by Giacomin, Jansses, Pruett, Shinnar, Llopis and Toney ${ }^{2}$. It includes data on entrepreneurial intentions, motivations and barriers from students studying in Belgium, US, China, India and Spain. Based on questionnaire with 20 items focused on barriers the most significant among them are given below (authors have taken into account variations according country to country results):

- lack of support structure and fiscal or administrative costs;

- lack of knowledge and experience;

- economic climate and lack of entrepreneurial competencies;

- lack of self-confidence;

- risk aversion.

Some of the authors with interest in the field make different scope studies of barriers to starting a business for students by studying students in specific specialties. Khayri, Yaghoubi \& Yazdanpanah studied the barriers of 100 agricultural graduated students in Zanjan University, Iran ${ }^{3}$ deriving the following, ranked in order of importance: duates;

- weak government support for agriculture gra-

- financial inability to provide employment arrangements in the agricultural sector;

- inefficacy of the universities in training graduates;

- disproportion courses offered in agricultural colleges with labor market needs;
- limitation of career opportunities in agriculture;

- low levels of employment knowledge and skills of agricultural graduates;

- low level of creativity in graduates because of inappropriate teaching methods in university;

- graduates lack of interest to the agricultural sector jobs.

Among the barriers identified by Iranian students, those related to university education are particularly impressive - ineffective education, inadequate teaching methods, etc., which are clearly presented as a significant obstacle for young people for their further development in entrepreneurship.

In another study conducted among 500 first- and second-year students studying management in the University of Pune, India a very serious barrier was highlighted: unavailability of capital, followed by: absence of government policies and support as it was meant that is not available easily or a bureaucratic hassle for getting various certificate and clearances is not easy; to have favourable set of environmental conditions to set up and run business along with available raw materials, etc. The conclusion is: "it seems management education is for getting corporate job instead of starting own business unlike other professional education"4 and despite government efforts to promote entrepreneurial careers among young people, the results are still quite poor.

224 bachelor polytechnics students studying Hospitality and catering management specialties at Takoradi polytechnic, Ghana outlined following barriers: lack of government support, lack of funding, lack of funding information about government agencies that can assist in funding business, lack of exposure, and fear of failure ${ }^{5}$. The authors concluded that usually these students are trained how to manage/run a related business excellently and the study indicated that most of the respondents surveyed had the intention of starting up their own business. Although they marked the challenge of knowledge of support services and facilities, and above all notable barriers that practically, prevent them from doing so. This together with other distant factors quenches the desire to take the initiative.

A kind of summary of what has been said so far can be considered the classification of barriers by Sitaridis,

\footnotetext{
${ }^{1}$ Zahorsky, D. Breaking the 5 Biggest Barriers to Starting a Business (January 30, 2020). URL: https://www.thebalancesmb.com/barriers-to-starting-a-business-2951831.

${ }^{2}$ Giacomin, O., Janssen, F., Pruett, M., Shinnar, R. S., Llopis, F. \& Toney, B. (2011). Entrepreneurial intentions, motivations and barriers: Differences among American, Asian and European students. International Entrepreneurship and Management Journal, Vol. June 2011, pp. 219-238 (p. 234, p. 226-230). doi 10.1007/s11365-010-0155-y.

${ }^{3}$ Khayri, Sh., Yaghoubi, J. \& Yazdanpanah, M. (2011). Investigating barriers to enhance entrepreneurship in agricultural higher education from the perspective of graduate students. Procedia Social and Behavioral Sciences, Vol. 15, pp. $2818-2822$.

${ }^{4}$ Pahurkar, R., Kolte, As. \& Jain, S. (2020). A Study of Perceived Barriers for Entrepreneurship Development among Management Students. Test Engineering and Management, March-April, pp. 5607-5620. URL: https://www.researchgate.net/ publication/341120956_A_Study_of_Perceived_Barriers_for_Entrepreneurship_Development_among_Management_Students.

${ }^{5}$ Asiedu, M. \& Nduro, Kw. (2015). Polytechnic Students' Entrepreneurial Knowledge, Preferences and Perceived Barriers to Start-Up Business. European Journal of Business and Management, Vol.7, No.21, pp. 20-28.
} 
$\&$ Kitsios $^{1}$. They proposed the classification after investigating 81 articles with a focus on the subject or related subjects. Based on their research, they classify the barriers into two large groups: internal and external, presented in Fig. 1.

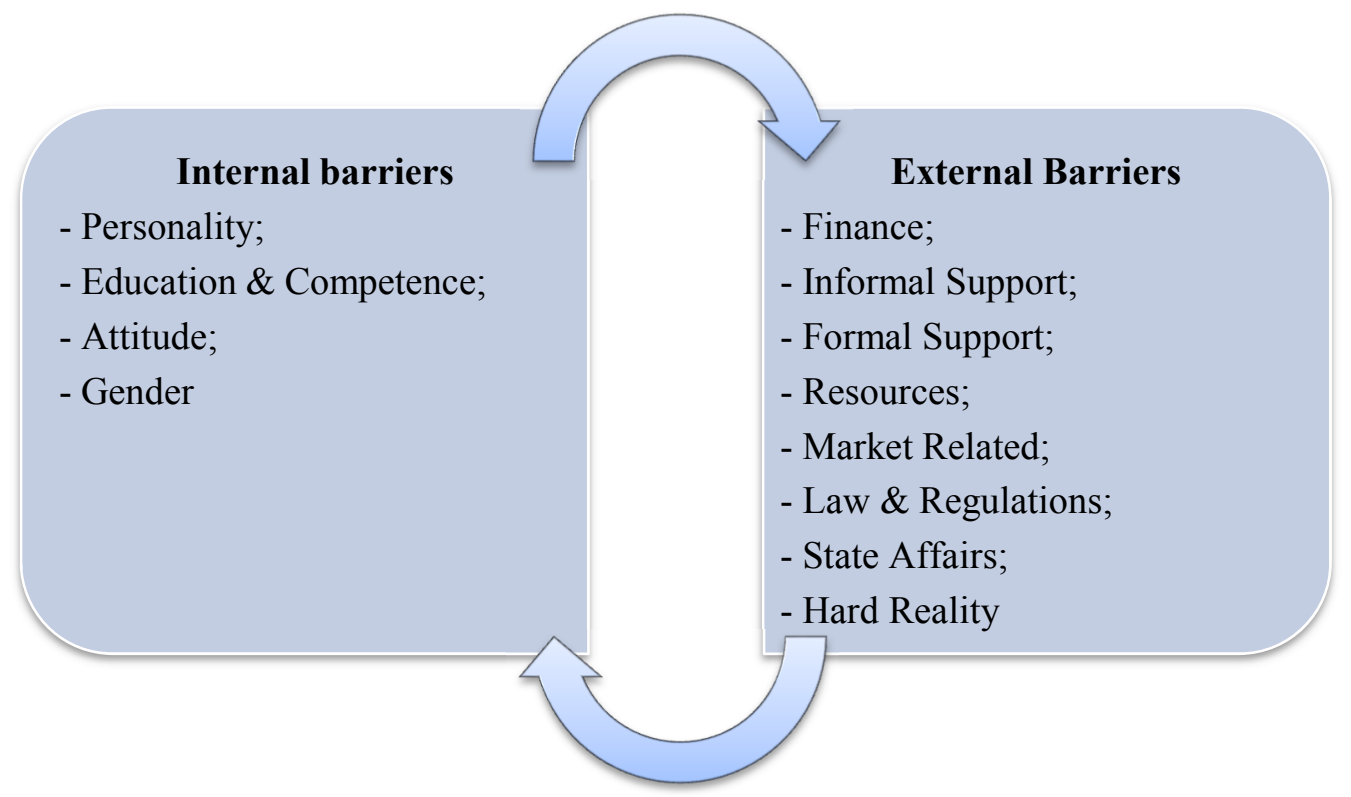

Fig. 1. Internal and external barriers by Sitaridis \& Kitsios

The identified barriers were tested among 81 postgraduate students of applied informatics of University of Macedonia, Greece. Students specified two main factors influencing them concerning turning entrepreneurial intentions into real business activities: role of education to reorient students' career choices towards entrepreneurship, and additionally to make students capable of devising ways to overcome the conceivable barriers; and policy makers need to reduce the actual or perceived barriers through appropriate entrepreneurship support measures, in order to successfully overcome economic stagnation. This study proves once again that modern and adequate to the needs of students entrepreneurship education, plays a significant role in orienting them to entrepreneurial careers. Its absence or incorrect construction can be easily overcome with the help of contemporary training tools, including chatbot solutions, thus directing more young people to implement entrepreneurial projects in various formats.

\section{Empirical Study Results design \\ II.1. Research framework and questionnaire}

The study of barriers for starting a business by students studying at universities in Bulgaria and Poland was carried out in the period from January to March
2020. A total of 120 students were questioned, 60 at each university. The questionnaires consist of three sections with closed questions: intentions, motives and barriers to starting a business as for a base for its construction is used a questionnaire developed by Hristova \& Vasilska $^{2}$. This article analyses the results of the first and fourth sections. Opinions' analysed are given by students attending Bachelor and Master Degrees with distribution as follows:

- Bachelors 1st semester - 60;

- Bachelors 4th semester - 30;

- Masters 1st and 2nd semester - 30 .

Specialties of the surveyed Bulgarian students are in the field of economy, management and business linguistics (social sciences), as specialties of Polish students are Geo-informatics, Geodesy and Cartography and Computer Science, generally speaking technical studies.

\section{II.2. Entrepreneurial intentions for starting a} business by students

Summarized data from the question regarding intentions for starting a business are given in fig. 2. Small part of the surveyed students $-12 \%$, indicates that they do not intend to start their own business and prefer to be employed. The remaining $88 \%$ expressed a positive at-

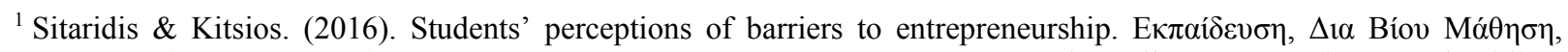

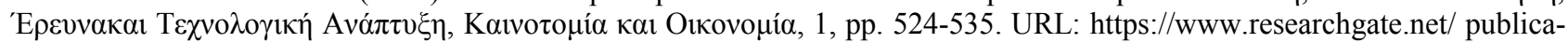
tion/317109641_Students'_perceptions_of_barriers_to_entrepreneurship [accessed Sep 13 2020].

${ }^{2}$ Hristova, V. \& Vasilska, M. (2018). On entrepreneurial intentions - some aspects of survey results. In: Collective Scientific Book of Faculty of Economics, "St. Cyril and St. Methodius" University of Veliko Tarnovo Annual Conference, dedicated to the 25th anniversary of the Faculty establishment, 28-29.09.2017, Veliko Tarnovo: University publishing house, ISSN 2603-4093, pp. $175-183$. 
titude towards the entrepreneurial initiative, with the majority of them - 61 out of 120 counting on the emergence of an idea that could be their own endeavour.
$4 \%$ of the surveyed are ready to start within 1 year, and only 2 students have already had a small business they manage.

f) Yes, but under certain conditions

e) Yes, but only if I come up with an idea that is worth the risk

d) Yes, but after having sufficient work experience as an employee

c) Yes, up to three years

b) Yes, within one year

a) No
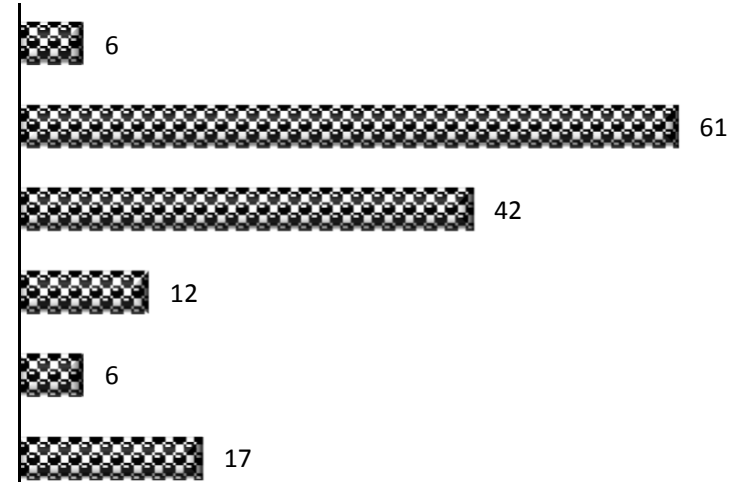

$\begin{array}{llllllll}0 & 10 & 20 & 30 & 40 & 50 & 60 & 70\end{array}$

Fig. 2. Distribution of answers to question „Do you intend to start your own business"?

The data show that most of the students have intentions related to entrepreneurship in the short, medium or long term. Unfortunately, such comparable at national level data are not available for a longer period of time, due to the partial monitoring of the indicator for Bulgaria (GEM). Although this we can see that the index in Bulgaria is with significantly lower levels than in Poland.

Entrepreneurial intentions rate for Poland and Bulgaria (2015-2019)

\begin{tabular}{|l|c|c|c|c|c|}
\hline \multicolumn{1}{|c|}{ Country } & $\mathbf{2 0 1 5}$ & $\mathbf{2 0 1 6}$ & $\mathbf{2 0 1 7}$ & $\mathbf{2 0 1 8}$ & $\mathbf{2 0 1 9}$ \\
\hline Bulgaria & 5.34 & 7.09 & 5.01 & 3.9 & na \\
\hline Poland & 19.97 & 20.83 & 9.69 & 9.48 & 6.00 \\
\hline
\end{tabular}

Source: GEM. URL: https://www.gemconsortium.org/data.

\section{II.3. Main barriers that prevent students to start} their own business

The summary of the data on barriers to students when starting a business showed several interesting moments:

- the ranking by importance of the data is quite different from the point of view of the nationality of the students as the strong barriers for the Bulgarian students are not the same for the Polish ones and vice versa;

- some of the very significant and insignificant barriers for Polish students have very similar values;

- a careful study of the data by Polish students indicates a number of barriers that they do not actually identify as such;

- in the data obtained from the Bulgarian students the grouping by importance of the barriers is more clearly distinguished as very strong, with medium significance and insignificant.

Based on the above, we assume that the data obtained in five scales can be summarized in a three-point scale, thus allowing for a clearer delineation of the groups of barriers relevant to the students studied. The summarized data are presented in Table 2, which shows that the most important is the barrier "Lack or insufficient financial resources", which was noted by $67 \%$ of respondents. The immanent characteristic of entrepre- neurship "High risk and uncertainty" (57\%) is considered as a significant barrier to the implementation of future entrepreneurial initiatives. At a third place is the barrier "Regulatory, technological and other barriers to the realization of my idea" with $48 \%$, followed by "Corruption" (47.5\%), "Lack of knowledge / insufficient information on research transfer mechanisms" (46.7\%) and "Strong competition" (45.8\%). "Absence / low attendance of entrepreneurial spirit and qualities in secondary school curricula", "Availability and access to information" and "Limited access to national and international markets" have been identified as barriers with the lowest significance around and below $30 \%$.

As other reasons for preventing starting a business are pointed such as: laziness, demand for services in a given city, language barriers, the Right motivation, lack of experience, too much responsibility, too little professional experience, etc.

As noted, there are significant differences between the data of Bulgarian and Polish students. Undoubtedly, for both groups of questioned students the most serious problem is the lack of sufficient financial resources. However, the next most important barriers are arranged differently and indicate different problem areas in both countries. The visualization of the 5 most important problem areas is given in Fig. 3. 
The summary of "What are the reasons that would prevent you from starting a business?" question, arranged in descending order by groups

\begin{tabular}{|c|c|c|c|c|}
\hline $\begin{array}{l}\text { Group of } \\
\text { barriers }\end{array}$ & Barriers before students to start their own business & Not true & $\begin{array}{l}\text { Neither true } \\
\text { nor no }\end{array}$ & True \\
\hline \multirow{6}{*}{ 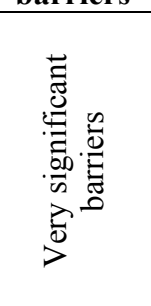 } & Lack or insufficient financial resources & 10 & 30 & 80 \\
\hline & High risk and uncertainty & 21 & 29 & 68 \\
\hline & $\begin{array}{l}\text { Regulatory, technological and other barriers to the realization of } \\
\text { my idea }\end{array}$ & 27 & 32 & 58 \\
\hline & Corruption & 32 & 30 & 57 \\
\hline & $\begin{array}{l}\text { Lack of knowledge / insufficient information on research transfer } \\
\text { mechanisms }\end{array}$ & 27 & 34 & 56 \\
\hline & Strong competition & 24 & 40 & 55 \\
\hline \multirow{4}{*}{ 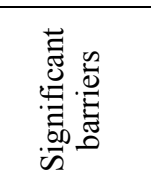 } & Weak / limited government policy & 20 & 45 & 53 \\
\hline & Absence / poor awareness of support programs & 22 & 44 & 52 \\
\hline & $\begin{array}{l}\text { My lack of knowledge and skills, despite my entrepreneurship } \\
\text { training }\end{array}$ & 34 & 34 & 51 \\
\hline & Poor economic climate & 37 & 33 & 48 \\
\hline \multirow{7}{*}{ 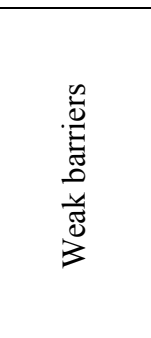 } & Features of the workforce in the country & 32 & 45 & 43 \\
\hline & Different perspective of SMEs and large companies & 22 & 54 & 43 \\
\hline & Political, institutional and social context & 33 & 44 & 42 \\
\hline & $\begin{array}{l}\text { Imposed negative cultural and social norms in the country on en- } \\
\text { trepreneurship - e.g. low propensity to take entrepreneurial risk }\end{array}$ & 36 & 39 & 42 \\
\hline & $\begin{array}{l}\text { Absence / low attendance of entrepreneurial spirit and qualities } \\
\text { in secondary school curricula }\end{array}$ & 41 & 41 & 38 \\
\hline & Availability and access to information & 50 & 39 & 29 \\
\hline & Limited access to national and international markets & 14 & 25 & 20 \\
\hline
\end{tabular}

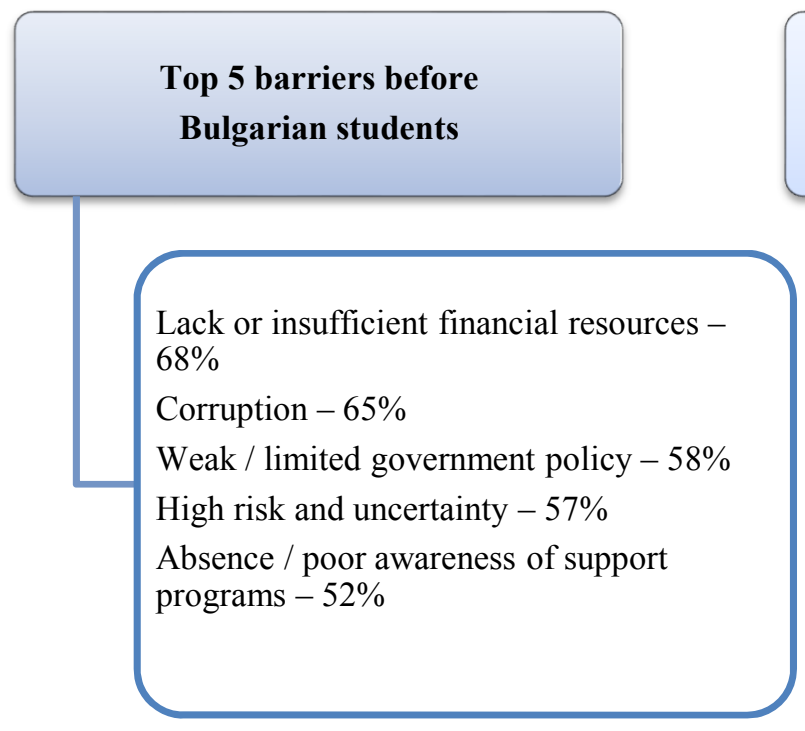

Fig. 3. Leading barriers for Bulgarian and Polish students when starting a business

The widely identified and discussed corruption problem in Bulgaria is noted as a very significant barrier by Bulgarian students, while for their Polish counterparts this problem falls into the group of barriers of little importance and as such is noted by only $1 / 3$ of them. Bulgarian students also see a significant absence on state programs and policies in support of entrepreneurship in general. Polish students emphasize the lack of training in the acquisition of entrepreneurial knowledge and skills and rank these barriers among the most important. It is noteworthy that it seems that Polish students tend to look for the reasons for refraining from entrepreneurship rather in themselves, while for Bulgarian students the emphasis is directed outside the individual - to the state.

From the point of the stage of students' education, the summarized data outline the following picture: for first-year students the most significant barrier for both groups of students is "Lack or insufficient financial resources"; for students from 4 semester the point of contact is about the barrier "High risk and uncertainty", while for Master students at both studied groups we can see the barriers: "Lack or insufficient financial resources" and "High risk and uncertainty". 


\section{II.4. Differences between groups of students in Poland}

Definitely "Lack or insufficient financial resources" is the main challenge for young people that prevent them to start the business. Such result can be expected also in other countries and continents. In Poland, all groups, despite experience level, have chosen that answer most frequently.

The second highest scored results in Poland is "High risk and uncertainty". In this case situation between groups is different. Despite this is very popular answer in the whole Polish group, it is not so common amongst younger group. It can be assumed, that during the education process, students gain knowledge, what brings them into the higher level of uncertainly. The less you know the better? A very controversial sentence, particularly in the education institution. The same meaning, but sounds better: "I know that I know nothing". How many people after graduation can say so?

The third most popular answer "Lack of knowledge / insufficient information on research transfer mechanisms" brings reverse tendency. For the youngest group it is more challenging that for older groups. This conclusion is consistent with the previous one. Master group is more experienced, or at least should be more experienced that 1 st semester students. At the same time, Master students, based on own experience, can identify more barriers and risks when starting own business. The ability to take risks decreases with age. Creativity level decline during the education process as we are trained, that only one answer is correct. This is the effect of the widespread use of tests to verify knowledge. And when all answers except one are wrong, it is really very risky to take any action.

As the barriers with the lowest level, Polish students indicated:

"Limited access to national and international markets" and "Corruption". These two barriers are somehow correlated as access to the market can be limited by corruption. In other words, paying a bribe, in some countries, can open up business opportunities. Of course corruption generally limits the access to the market and therefore creates huge barrier to start the business.

\section{II.5. Differences between groups of students in Bulgaria}

The summarized data of Bulgarian students' answers also indicated interesting differences. The studied students are economics and their disciplines focus exclusively on the peculiarities of the internal and external environment in which organizations work and develop their endeavors. This fragmentarily explains the answers they give regarding barriers to starting a business.

Regarding their entrepreneurial intentions, the most frequently mentioned answer from them was Yes, but only if I come up with an idea that is worth the risk. The highest results here were given by the Master students $-87 \%$, followed by the $2^{\text {nd }}$ semester students $73 \%$ and lastly the bachelors from the $4^{\text {th }}$ semester with only $40 \%$. According to these data, it is convincing that students studying in Master programs are highly entrepreneurial in recognizing an idea that they think would be more respectable, as some of them indicated that they intend to develop entrepreneurial projects within existing business structures, i.e. they pointed out the intrapreneurial career as desired development path. These data are logical, as the specialties studied by the students suggest enhanced entrepreneurial behavior inside and outside the existing business structures. We also have to point that only 3 students -1 from each group, have convincingly stated that they did not intend to start their own business.

Analysis of students' data by course of studying shows that there are some differences which barriers are considered as significant and discourage students from starting their own businesses. It is an interesting fact that only half of the $1^{\text {st }}$ year students pointed the lack of sufficient knowledge in the field of entrepreneurship as a significant barrier, and a significantly larger part of them emphasize the lack of funds, corruption, lack of sufficient state support and high risk. Almost similar barriers are identified by $2^{\text {nd }}$ year students, but unlike $1^{\text {st }}$ year students, just under half of them point to the lack of sufficient financial instruments to start a business as a very significant barrier. The masters again emphasize the barriers, lack of sufficient financial resources and corruption. It is noteworthy that the barriers indicated in third and fourth place for the three groups of students studied are identical, namely "High risk and uncertainty" and "Weak / limited government policy".

Table 3

Summarized "Very significant" barriers before students to start own business by levels of study, $\%{ }^{1}$

\begin{tabular}{|c|c|c|c|c|c|c|c|c|}
\hline & Barriers & $\%$ & & Barriers & $\%$ & & Barriers & $\%$ \\
\hline \multirow{5}{*}{ 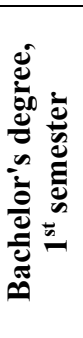 } & $\begin{array}{l}\text { Lack or insufficient } \\
\text { financial resources }\end{array}$ & 77 & \multirow{5}{*}{ 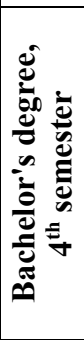 } & Corruption & 73 & \multirow{5}{*}{ 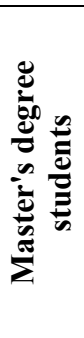 } & $\begin{array}{l}\text { Lack or insufficient } \\
\text { financial resources }\end{array}$ & 73 \\
\hline & Corruption & 60 & & Poor economic climate & 60 & & Corruption & 67 \\
\hline & $\begin{array}{l}\text { High risk and uncer- } \\
\text { tainty }\end{array}$ & 57 & & $\begin{array}{l}\text { High risk and uncer- } \\
\text { tainty }\end{array}$ & 60 & & $\begin{array}{l}\text { High risk and uncer- } \\
\text { tainty }\end{array}$ & 67 \\
\hline & $\begin{array}{l}\text { Weak / limited govern- } \\
\text { ment policy }\end{array}$ & 57 & & $\begin{array}{l}\text { Weak/limited govern- } \\
\text { ment policy }\end{array}$ & 53 & & $\begin{array}{l}\text { Weak / limited govern- } \\
\text { ment policy }\end{array}$ & 67 \\
\hline & \begin{tabular}{|l|} 
Absence / poor aware- \\
ness of support programs
\end{tabular} & 57 & & $\begin{array}{l}\text { Political, institutional } \\
\text { and social context }\end{array}$ & 53 & & $\begin{array}{l}\text { Regulatory, technologi- } \\
\text { cal and other barriers }\end{array}$ & 67 \\
\hline
\end{tabular}

${ }^{1 .}$ Multiply answers were accepted. 
Summarizing the biggest barriers before Bulgarian students are: Lack or insufficient financial resources and Corruption. As barriers with the lowest levels, they indicate the following:

- Bachelor's degree, $1^{\text {st }}$ semester - Absence / low attendance of entrepreneurial spirit and qualities in secondary school curricula $-27 \%$;

- Bachelor's degree, $4^{\text {th }}$ semester - Availability and access to information $-13 \%$;

- Master's degree students $-27 \%$.

\section{Conclusion}

"Lack or insufficient financial resources" is a factor which definitely joins young entrepreneurs from Bulgaria and Poland. Authors did not extend their researchers outside those countries. However, it can be assumed with the high probability, that this barrier is one of the main barriers also worldwide. From the other side it is also a very convenient excuse: "I do not have money to make a business". It can be rephrased: "I do not have money to make money". This is one of the main challenges for teachers, mentors, coaches etc., particularly those, who linked with entrepreneurship education. How to convince young people that it is possible to start the business without money? It is possible, when there is a proper government policy and there is no corruption. On two mentioned factors, education institutions can have an influence. It is somehow limited as it is not a direct influence. However proper education of young people should bring the desired results in the future. Education institutions have direct influence on the level of knowledge and skills among young generation. Polish students pointed out lack of knowledge and skills. This can be explained by the lack of economic education (Maritime University). Bulgarian students, who study at economic departments, do not underline this barrier. From the other side, do we need economic experience to start the business?

Final conclusion: do all those barriers, except corruption, exist only in our heads? Does the education process deliver together with knowledge more and more barriers? Does the education process create the feeling that only one solution is good (tests, tests, tests) and therefore generates a fear of taking a risk/prototype? Do children in kindergarten afraid to prototype? No, therefore they can create two times higher Marshmallow towers than business school students" . "Imagination is more important than knowledge" Albert Einstein.

\section{References}

1. 10 Reasons Why Entrepreneur Fail Their Business, HarvardEntrepreneurships. Retrieved from https: //www.harvardentrepreneurship.org/246/10-reasons-why- entrepreneur-fail-their-business.html (posted on July 2, 2020).

2. Asiedu, M. \& Nduro, Kw. (2015). Polytechnic Students' Entrepreneurial Knowledge, Preferences and Perceived Barriers to Start-Up Business. European Journal of Business and Management, Vol. 7, No. 21, pp. 20-28.

3. Deneva, A. (2001). The small business - organization and problems. Economic world Library, No. 51. Svishtov, Tsenov Publishing house [in Bulgarian].

4. GEM. Retrieved from https://www.gemconsortium.org/data.

5. Giacomin, O., Janssen, F., Pruett, M., Shinnar, R., Llopis, F. \& Toney, B. (2011). Entrepreneurial intentions, motivations and barriers: Differences among American, Asian and European students. International Entrepreneurship and Management Journal, Vol. June 2011, pp. 219238 (p. 234, p. 226-230). doi: 10.1007/s11365-010-0155-y.

6. Hristova, V. \& Vasilska, M. (2018). On entrepreneurial intentions - some aspects of survey results. In: Collective Scientific Book of Faculty of Economics, "St. Cyril and St. Methodius" University of Veliko Tarnovo Annual Conference, dedicated to the 25th anniversary of the Faculty establishment, 28-29.09.2017. (Pp. 175-183). Veliko Tarnovo, University publishing house.

7. Khayri, Sh., Yaghoubi, J. \& Yazdanpanah, M. (2011). Investigating barriers to enhance entrepreneurship in agricultural higher education from the perspective of graduate students. Procedia Social and Behavioral Sciences, vol. 15, pp. 2818-2822.

8. Pahurkar, R., Kolte, As. \& Jain, S. (2020). A Study of Perceived Barriers for Entrepreneurship Development among Management Students. Test Engineering and Management, March-April, pp. 5607-5620. Retrieved from https://www.researchgate.net/publication/341120956_A Study_of_Perceived_Barriers_for_Entrepreneurship_Development_among_Management_Students.

9. Pavlov, D., Sheresheva, M., Perello, M. (2017). The Intergenerational Small Family Enterprises as Strategic Entities for the Future of the European Civilization - A Point of View. Journal of Entrepreneurship \& Innovation, Issue 9, pp. 121-133.

10. Sitaridis \& Kitsios. (2016). Students' perceptions

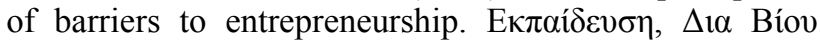

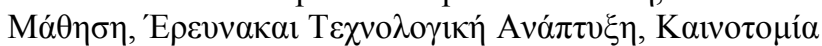

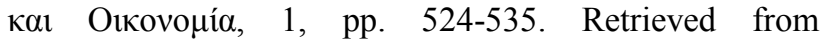
https://www.researchgate.net/publication/317109641_Students'_perceptions_of_barriers_to_entrepreneurship ${ }^{-}$[accessed Sep 13 2020].

11. Teach your students, why business plans fail. Retrieved from https://www.teachingentrepreneurship.org/ why-business-plans-fail/ [access 22.09.2020].

12. Zahorsky, D. (January 30, 2020). Breaking the 5 Biggest Barriers to Starting a Business. Retrieved from https://www.thebalancesmb.com/barriers-to-starting-abusiness-2951831.

${ }^{1}$ Teach your students, why business plans fail. URL: https://www.teachingentrepreneurship.org/why-business-plans-fail/ [access 22.09.2020]. 
Христова В., Волейша П. Бар'єри перед підприсмницькими намірами і бізнес-ініціативами студентів - результати емпіричного дослідження серед болгарських та польських студентів

У статті представлено найбільш важливі перешкоди для болгарських та польських студентів, через які вони відмовляються від своїх підприємницьких намірів або значно скорочують їх реалізацію та відкриття нового бізнесу. Існують значні і різноманітні перешкоди на шляху здійснення підприємницької діяльності, але особливо важливо, щоб вони були позначені для молодих людей з бажанням і намірами до підприємництва. Підприємницька діяльність, що розвивається молодими освіченими людьми, дуже важлива для ініціювання та виявлення змін в структурах економіки і суспільства. Все більш важливе місце в цьому процесі займають вищі навчальні заклади, які при відповідній підготовці можуть «перетворити» наміри в реальну підприємницьку діяльність або повністю заблокувати людей 3 великим підприємницьким потенціалом. Мета цієї статті - виділити деякі ключові перешкоди, що заважають студентам розвивати свої ділові наміри й ініціативи. Вони засновані на опитуванні, проведеному в Болгарії і Польщі серед студентів, які вивчають підприємницькі дисципліни в університеті «Св. Кирила і Св. Мефодія» у Велико Тирново (Болгарія) і Морському університеті Щецина (Польща). На підставі цього робляться деякі висновки і даються рекомендації університетам з точки зору посилення їх ролі як зовнішніх мотиваторів для запуску студентами різних підприємницьких проєктів.

Ключові слова: підприємництво, потенціал, бар'єри, бізнес-наміри студентів, відкриття бізнесу, університет.

Hristova V., Wołejsza P. Barriers before Students` Entrepreneurial Intentions and Business Initiatives Results by Empirical Study of Bulgarian and Polish Students

This article outlines the most important barriers for Bulgarian and Polish students that abandon or significantly reduce the execution of their entrepreneurial intentions and the start of new businesses. There are significant and diverse barriers in the implementation of entrepreneurial activities, but it is especially important that they are outlined for young people with a desire and intentions for entrepreneurship. Entrepreneurial activities developed by young educated people are very important for the initiating and identifying changes in the economy's and society's structures. An increasingly important place in this process is taken by higher education institutions, which with their adequate training can "turn" intentions into real entrepre- neurial activities or completely lock people with great potential for entrepreneurship. The aim of this article is to highlight some key barriers preventing students to develop their business intentions and initiatives. They are based on a survey conducted in Bulgaria and Poland among students studying entrepreneurial subjects at the "St. Cyril and St. Methodius" University of Veliko Tarnovo and Maritime University of Szczecin, Poland. On this basis, some conclusions are outlined and recommendations are made to universities in terms of strengthening their role as external motivators for launching various entrepreneurial projects by their students.

Keywords: entrepreneurship, potential, barriers, students' business intentions, starting a business, university.

Христова В., Волейша П. Барьеры перед предпринимательскими намерениями и бизнес-инициативами студентов - результаты эмпирического исследования среди болгарских и польских студентов

В статье описаны наиболее важные препятствия для болгарских и польских студентов, которые отказываются от своих предпринимательских намерений или значительно сокращают их реализацию и открытие нового бизнеса. Существуют значительные и разнообразные препятствия на пути осуществления предпринимательской деятельности, но особенно важно, чтобы они были обозначены для молодых людей с желанием и намерениями к предпринимательству. Предпринимательская деятельность, развиваемая молодыми образованными людьми, очень важна для инициирования и выявления изменений в структурах экономики и общества. Всё более важное место в этом процессе занимают высшие учебные заведения, которые при соответствующей подготовке могут «превратить» намерения в реальную предпринимательскую деятельность или полностью заблокировать людей с большим предпринимательским потенциалом. Цель этой статьи - выделить некоторые ключевые препятствия, мешающие студентам развивать свои деловые намерения и инициативы. Они основаны на опросе, проведенном в Болгарии и Польше среди студентов, изучающих предпринимательские дисциплины в университете «Св. Кирилла и Св. Мефодия» Велико Тырново (Болгария) и Морском университете Щецина (Польша). На основании этого делаются некоторые выводы и даются рекомендации университетам с точки зрения усиления их роли как внешних мотиваторов для запуска студентами различных предпринимательских проектов.

Ключевые слова: предпринимательство, потенциал, барьеры, бизнес-намерения студентов, открытие бизнеса, университет.

Received by the editors: 12.10 .2020 and final form 29.12.2020 